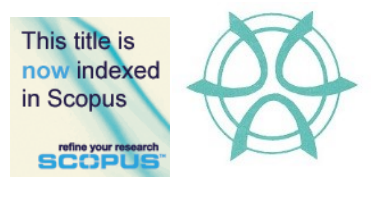

PLANNING MALAYSIA:

Journal of the Malaysian Institute of Planners

VOLUME 18 ISSUE 3 (2020), Page 25 - 34

\title{
POST-CONSERVATION EVALUATION (PCE): FINANCIAL PERFORMANCE OF ADAPTIVE REUSE MUSEUMS IN GEORGE TOWN, MALAYSIA
}

\author{
Muhammad Firzan Abdul Aziz \\ School of Housing, Building and Planning \\ UNIVERSITI SAINS MALAYSIA
}

\begin{abstract}
Adaptive reuse of historic buildings has become a prominent trend in the scenario of built heritage conservation of Melaka and George Town, UNESCO World Heritage Sites of Malaysia. Such implementation however is questionable since there have been several dilemmas raised in relation to the local museum industry. Among them are stiff competition faced by museums as an attractive cultural product, not appealing to business funders, rarely favoured as a family holiday destination and being perceived as dull and old repositories by the younger generations. As adaptive reuse is known to revive the physical and functional facets of historic building which then contributes to its economic generation, this study attempts to understand the financial impact from such implementations. Post-conservation evaluation (PCE) focusing on financial performance was conducted on adaptive reuse museums in the Core Zone and Buffer Zone of George Town, involving Penang State Museum (PSM), Made in Penang Interactive Museum (MIPIM), Batik Painting Museum (BPM) and Dark Mansion-3D Glow in the Dark Museum (DM) which were shortlisted trough purposive sampling. Key informants' survey was then carried by engaging key person identified to be resourceful and knowledgeable with the respective museums' financial background and history. It is found that the adaptive reuse museums have yet to gain a stable return of investment, due to low-income generation from their ticketing sales in relation to higher operational and maintenance costs they require. By conducting PCE on the financial performance of adaptive reuse buildings that are of cultural and historical values, conservation stakeholders may be furnished with better information that aids better decisionmaking in the future.
\end{abstract}

Keywords: Adaptive reuse museum, financial performance, historic building, post-conservation evaluation (PCE), UNESCO World Heritage Site

${ }^{1}$ Corresponding author's email: firzan@usm.my 
Muhammad Firzan Abdul Aziz

Post-Conservation Evaluation (PCE): Financial Performance of Adaptive Reuse Museums in George Town, Malaysia

\section{INTRODUCTION}

Apparently, many cities nowadays opted for adaptive reuse as a means of urban revitalisation and conservation. Conservation of built heritage, through adaptive reuse of historic buildings within heritage sites has been long associated with the agenda of sustainability. Such implementation is deemed vital in meeting sustainable development through the trifold environmental, social and economic dimensions (Feilden, 2000; Bullen P., 2007; Godwin, 2011). In Malaysia, Melaka and George Town have been inscribed in the UNESCO World Heritage Sites on 7th July 2008. Under the cultural heritage category, Melaka and George Town have been revered as the Historic Cities of the Straits of Malacca for their Outstanding Universal Values (OUVs) comprising both tangible and intangible heritage. One of the significant conservation trends apparent in Melaka and George Town is the act of converting old buildings to museums.

The scenario however raised a question on the financial impacts of adaptive reuse museums since there have been several dilemmas raised in relation to the local museum industry. Years before the inscription date, Rowley (1999) already found that museums face a stiff competition in attracting tourists, by having to compete with other leisure and touristic destination spots. Former general director of the Department of Museums Malaysia, Dato' Dr Adi Taha meanwhile reported that Malaysian museums have always been unattractive by financial providers due to their poor capability in generating revenue to the nation (Taha, 2009). Later, another former general director, Datuk Ibrahim Ismail affirmed that Malaysian museums were rarely being listed as a favourable family destination trip compared to other holiday destinations (Abdul Razak, 2011). More recently, Datuk Seri Mohd Shafie Apdal, a local politician, observed that museums have been perceived as old and dull repositories which are not worth of attention for the younger generations (Mokhtar \& Kasim, 2012).

The prevalence of adapting historic buildings to museums is testified as $44 \%$ ( 27 out of the total 61) of museum buildings in Melaka and George Town were found to be adaptive reuse museums (Abdul Aziz, 2018). Acknowledging that adaptive reuse implementation can bring positive physical, functional and financial outcomes to historic building, this paper presents the post-conservation evaluation (PCE) made in regard to financial performance of adaptive reuse museums in George Town. George Town is the capital city for the state of Penang which has the highest number of historic buildings in Malaysia (Kamaruzzaman $\&$ Zulkifli, 2014). As there is a paucity of studies made on private museums compared to public museums in Malaysia, this paper would further enlighten on the financial performance of adaptive reuse museums in George Town, which are mostly owned by private individuals and agencies. 
PLANNING MALAYSIA

Journal of the Malaysia Institute of Planners (2020)

\section{RESEARCH BACKGROUND}

Theoretically, adaptive reuse fosters rejuvenation and prolongation of physical and functional aspects of built heritage (Langston, Wong, Hui, \& Shen, 2008; Bullen \& Love, 2011; Kamal \& Ab Wahab, 2014). The concept of adaptive reuse has been heavily linked with financial resiliency of historic buildings, as financial revenue is the by-product of the physical and functional revitalisation. Moreover, return of investment of historic building is an important indicator of conservation success, as indoctrinated in the local conservation philosophy comprising the twofold criteria of (Keromo, 2000):

- Safeguarding heritage; to retain the authenticity of materials (type, colour and texture), architecture (construction technique and workmanship) and original use (function or type).

- Developing heritage; to utilise and leverage heritage for economic gains without forsaking its preservation and conservation.

Imperatively, one of the components of sustainable development is economic factors. Hence, it is sensible that adaptive reuse aims to revitalise and sustain old buildings, by giving them a new life through their operational and economical facets (Langston, Wong, Hui, \& Shen, 2008; Bullen \& Love, 2011; Kamal \& Ab Wahab, 2014). As generally discussed, the financial performance of a building arises from its physical and functional performances that includes the calculations of capital and recurrent (life-cycle) expenditures, depreciation, and efficiency of use etc. (Sapri \& Pitt, 2005). In this regard, building performance can be evaluated by understanding how the building performs financially through its economic sense (value for money or return of investment) (Leaman, Stevenson, $\&$ Bordass, 2010). Acknowledging that efficiency refers to the extent of which activities or the desired effects are achieved with the lowest possible use of resources or inputs (National Centre of Sustainability, 2011), Abdul Aziz (2018) scrutinised on financial efficiency of conserved historic buildings in his postconservation evaluation (PCE) studies.

Abdul Aziz's (2018) PCE attempted to understand the performance and impact of adaptive reuse implementation by reviewing Operating Expense Ratio (OER) that indicates the annual patterns of expenditure (focusing on their lifecycle costs of operational use and building maintenance) over income and revenue. Through the OER trends, building owners or investors can predict whether the property has been managed efficiently or profitable, by comparing the property's income coverage against its operational and maintenance costs. This is because, annual increment of the OER pattern signals that an investor may lose more money if he or she holds the property longer (Investopedia, LLC., 2014; DV, 2016). 
Muhammad Firzan Abdul Aziz

Post-Conservation Evaluation (PCE): Financial Performance of Adaptive Reuse Museums in George Town, Malaysia

Besides OER, an aspect of Contingency Valuation Method (CVM) commonly used to assess historic buildings known as willingness-to-pay (WTP), is also useful to assess the financial performance of conserved historic buildings. WTP is the theory used to understand the economic feasibility and sustainability of heritage sites. WTP is based on people's evaluation of cultural heritage, and their consumerism preference (Kim, Kevin, \& Cho, 2008; Choi, Ritchie, Papandrea, \& Bennett, 2010; Dong, Zhang, Zhi, Zong, \& Li, 2011; Noor Fazamimah, Anuar, \& Yahaya, 2015). WTP is meaningful in informing the return of investment for cultural heritage goods, typically valued through their consumption via entrance fees gained and conservation funds received (Beltran \& Rojas, 1996).

Apart from OER and WTP, consideration on building's economic performance through its life-cycle costs (LCC) is essential to determine costeffectiveness and later influence strategic, tactical and operational decisions (Dorasol, Mohammad, Mohammed, Hamadan, \& Nik Lah, 2012). Blanchard, Verma and Peterson (1995) reported that $50 \%$ to $80 \%$ of the total LCC is spent during in-service life. In this sense, the building operation and maintenance phase of LCC is crucial and has a major impact on building performance. NIBS (2009) described cost-effective building as the one that renders the lowest operating and maintenance costs, has the longest lifespan, encourages productivity among users and offers the greatest return on investment. Dorasol, Mohammad, Mohammed, Hamadan and Nik Lah (2012) added specifically that an efficient building is one that uses energy and water efficiently.

\section{METHODOLOGY}

Initially, purposive sampling was adopted to shortlist buildings from the total 29 museum buildings found in George Town. The two criteria used were i. location (buildings within the Core Zone and Buffer Zone of George Town) and ii. conservation (buildings of cultural, historical or architectural importance which have gone through adaptive reuse implementation). Then, a key informants survey was conducted at the shortlisted buildings, by engaging a key person from each of the shortlisted buildings. They were basically those identified to be resourceful and knowledgeable with the financial background and history of their respective museum. Timeline for the financial archive sought was from year 2008 (in conjunction with the inscription year of UNESCO World Heritage) to 2016 (year of data collection). A survey feedback form which probed on museum income and expenditure was used to retrieve and yield the OER patterns as shown in Figure 1. During its issuance, the survey form was first explained to the respective museum key informants to foster a better clarity and accuracy of data input. 
PLANNING MALAYSIA

Journal of the Malaysia Institute of Planners (2020)

\begin{tabular}{|c|c|c|c|c|c|}
\hline \multirow{2}{*}{\multicolumn{2}{|c|}{$\begin{array}{l}\text { Museum's } \\
\text { Financial } \\
\text { Performance } \\
\text { (Year \& Month) }\end{array}$}} & \multicolumn{2}{|c|}{ Income (RM) } & \multicolumn{2}{|c|}{ Expenditure (RM) } \\
\hline & & \multirow[t]{2}{*}{$\begin{array}{l}\text { Ticketing } \\
\text { Revenue } \\
\text { (based on no. of } \\
\text { visitors) }\end{array}$} & \multirow[t]{2}{*}{$\begin{array}{c}\text { Heritage } \\
\text { Conservation } \\
\text { Fund Received } \\
\text { (If any, please } \\
\text { state the source) }\end{array}$} & \multirow[t]{2}{*}{$\begin{array}{l}\text { Operational Costs } \\
\text { (utility bills such as } \\
\text { electricity, water } \\
\text { etc.) }\end{array}$} & \multirow[t]{2}{*}{$\begin{array}{l}\text { Building Maintenance } \\
\text { Costs } \\
\text { (If any, please state } \\
\text { which building } \\
\text { elements/areas) }\end{array}$} \\
\hline \multirow{7}{*}{ Year } & January & & & & \\
\hline & February & & & & \\
\hline & March & & & & \\
\hline & April & & & & \\
\hline & May & & & & \\
\hline & June & & & & \\
\hline & July & & & & \\
\hline & August & & & & \\
\hline & September & & & & \\
\hline & October & & & & \\
\hline & November & & & & \\
\hline & December & & & & \\
\hline & $\begin{array}{l}\text { (or Lump } \\
\text { Sum } \\
\text { Amount) }\end{array}$ & & & & \\
\hline
\end{tabular}

Figure 1: Screenshot preview of the key informants' survey form used for acquiring financial performance data

The survey form used entails columns on year and months, as well as on income and expenditure. The income column was subdivided into two sections of: i. Ticketing revenue (based on visitations) and ii. Heritage conservation fund received (based on financial grants or other monetary assistance received in relation to building conservation, if any). The expenditure column meanwhile was also sub-divided into two sections consisting: i. Operational costs (based on utility bills such as electricity, water and other expenses required for building operation) and ii. Building maintenance costs (based on maintenance or remedial works required on the building elements or areas). Upon feedback completion, the survey forms were then recollected for data analysis purposes. In line with the standard OER calculation method, the sum of museum expenditure was divided with the sum of museum income for each operational year of the museums. In this manner, declining annual OER trend would conclude that the building attained higher income over expenditure (financially efficient) and vice versa (financially inefficient). Since this study involved sensitive information on museums' financial archives, confidentiality of discreet records and voluntary participation were two ethical matters seriously concerned by the current researcher. Thus, raw data on the financial performance were not provided as an appendix in respecting confidential policy. 
Muhammad Firzan Abdul Aziz

Post-Conservation Evaluation (PCE): Financial Performance of Adaptive Reuse Museums in George Town, Malaysia

\section{ANALYSIS AND FINDINGS}

Based on the purposive sampling with the two aforementioned criteria applied, 14 out of total 29 adaptive reuse museums were shortlisted. However, only four out of the 14 adaptive reuse museums were accessible (consent granted by their respective museum owners or managers) namely Penang State Museum (PSM), Made in Penang Interactive Museum (MIPIM), Batik Painting Museum (BPM) and Dark Mansion-3D Glow in the Dark Museum (DM). Table 1 shows the key informants involved during the data collection period:

Table 1: Key informants involved from the adaptive reuse museums of George Town

\begin{tabular}{|c|c|}
\hline Museums & Key Informants' Position \\
\hline PSM & Museum assistant \\
\hline MIPIM & Museum co-owner and accounting staff \\
\hline BPM & Museum staff \\
\hline DM & Museum director \\
\hline
\end{tabular}

The four shortlisted adaptive reuse museums consisted of public and private museums based on their ownership. In the current study, the public museum involved was PSM which is government-owned operated by the Penang State Museum Board (PSMB). PSM's financial data were retrieved from the museum annual reports biennially published by PSMB, from year 2010 to 2014 which were available during the data collection period. Meanwhile, private museums involved in the current study consisted of those individually owned namely BPM and company-based ownership namely MIPIM and DM. Relatively, financial performance for the case of private museums were more difficult to be retrieved. This scenario was due to missing financial archives (for year 2013 and 2014 for BPM's case due to change of management) besides insufficient data to project OER pattern due to recent museum establishment (merely one-year financial data obtained for DM following its recent operational year). Table 2 summarises the individual results on OER of the adaptive reuse museums while Figure 2 projects their annual OER trends: 
Journal of the Malaysia Institute of Planners (2020)

Table 2: Individual results on the Operating Expense Ratio (OER) of the adaptive reuse museums

\begin{tabular}{|c|c|c|c|c|c|c|c|c|c|c|}
\hline & \multirow{2}{*}{\multicolumn{9}{|c|}{ Year }} \\
\hline & & & & & & & & & & \\
\hline & & 2008 & 2009 & 2010 & 2011 & 2012 & 2013 & 2014 & 2015 & 2016 \\
\hline \multirow{4}{*}{ 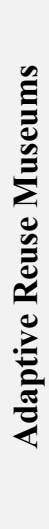 } & PSM & - & - & 0.14 & 0.10 & 0.11 & 0.13 & 0.12 & - & - \\
\hline & $\begin{array}{c}\text { MIPI } \\
\text { M }\end{array}$ & - & - & - & - & - & 0.13 & 0.02 & 0.11 & 0.11 \\
\hline & BPM & - & - & - & - & - & - & - & 0.29 & 0.46 \\
\hline & $\mathbf{D M}$ & - & - & - & - & - & - & - & - & 0.16 \\
\hline
\end{tabular}

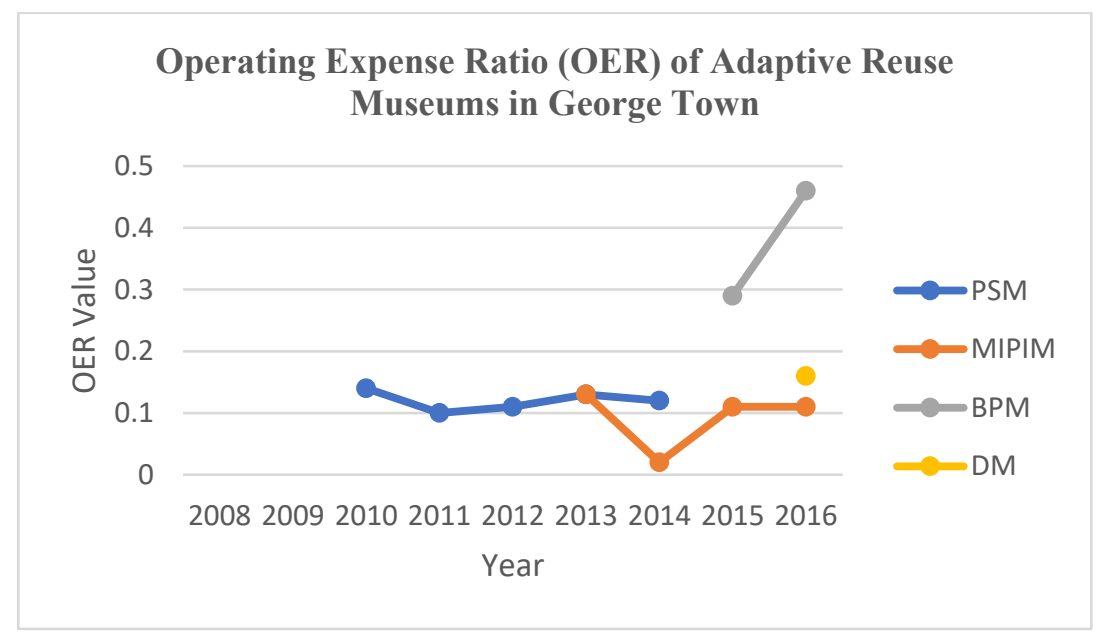

Figure 2: Annual trends on the Operating Expense Ratio (OER) of the adaptive reuse museums

Figure 2 depicts fluctuating OER trends for PSM and MIPIM, with an inclining OER trend for BPM. Implying from that, none of the four adaptive reuse museums shows a steadily declining OER trend throughout the years. It can be inferred that these historic buildings have yet to gain a stable return of investment 
Muhammad Firzan Abdul Aziz

Post-Conservation Evaluation (PCE): Financial Performance of Adaptive Reuse Museums in George Town, Malaysia

from their conversion to museums. They contradict the criterion of an efficient and profitable building which should have lesser coverage of revenue onto the operational and maintenance costs. Such scenarios can be associated with their low-income generation from ticketing sales in relation to the higher costs required for operating and maintaining the museum buildings. By forecast, the inclining OER trend of BPM signals that its investor may face financial loss for remaining the built property as a museum.

\section{CONCLUSION}

Summarily, the majority of the adaptive reuse museums have a steadily declining OER over the years. The trends generated however are deemed inadequate to conclude on the post-conservation impact of the adaptive reuse museums in George Town. This calls upon more comprehensive data on the museums' financial performance that span further annually in order to yield comprehensive OER trends. Since this study was limited by confidentiality and data inadequacy factors, future researchers are encouraged to expand and improve this study by retrieving more comprehensive data on financial performance from museum agencies. By conducting PCE focusing on financial performance of adaptive reuse buildings that are of cultural and historical values, conservation stakeholders such as the local authorities, building owners and conservators alike may be furnished with better information that aids better decision-making in the future. In this regard, PCE on financial performance as demonstrated in this paper, can be integrated with other impact evaluations to foster a more sustainable conservation planning and endeavours in protecting the Outstanding Universal Values of UNESCO World Heritage Sites.

\section{ACKNOWLEDGEMENT}

The author would like to appreciate the School of Housing, Building and Planning, Universiti Sains Malaysia (USM) for providing the financial support in publishing this article.

\section{REFERENCES}

Abdul Aziz, M. (2018). Post-Conservation Evaluation (PCE) Framework for Adaptive Reuse Museums: Case Studies of George Town, Malaysia (Doctoral dissertation). Kuala Lumpur, Malaysia: Universiti Malaya.

Abdul Razak, N. (2011). Cabaran 'hidupkan' muzium. Utusan Online. Retrieved from http://ww1.utusan.com.my/utusan/info.asp?y=2011\&dt=0524\&pub=Utusan_Mal aysia\&sec=Keluarga\&pg=ke_02.htm

Beltran, E., \& Rojas, M. (1996). Diversified funding methods in Mexican archeology. Annals of Tourism Research, 23(02), 463-478.

Blanchard, B., Verma, D., \& Peterson, E. (1995). Maintainability: A key to effective serviceability and maintenance management. New York: Wiley.

Bullen, P. (2007). Adaptive reuse and sustainability of commercial building. Facilities, 
25(1/2), 20-31.

Bullen, P., \& Love, P. (2011). Adaptive reuse of heritage buildings: Sustaining an icon or eyesore. COBRA 2011 Proceedings of RICS Construction and Property Conference (pp. 1652-1662). University of Salford.

Choi, A., Ritchie, B., Papandrea, F., \& Bennett, J. (2010). Economic valuation of cultural heritage sites: A choice modeling approach. Tourism Management, 31, 213-220.

Dong, X., Zhang, J., Zhi, R., Zong, S., \& Li, M. (2011). Measuring recreational value of World Heritage sites based on contingent valuation method: A case study of Jiuzhaigou. Chinese Geographical Science, 21(01), 119-128.

Dorasol, N., Mohammad, I., Mohammed, A., Hamadan, N., \& Nik Lah, N. (2012). Post occupancy evaluation performance criteria and parameters for hospital building in Malaysia. The 3rd International Conference on Business and Economic Research (ICBER), (pp. 2650-2667). Bandung, Indonesia.

DV. (2016). Financial ratio analysis. Retrieved from Demonstrating Value: https://www.demonstratingvalue.org/resources/financial-ratio-analysis

Feilden, B. (2000). Conservation of historic buildings. Oxford: Architectural Press.

Godwin, P. (2011). Building conservation and sustainability in the United Kingdom. Procedia Engineering, 20, 12-21.

Investopedia, LLC. (2014). Operating Expense Ratio - OER. Retrieved from Investopedia: http://www.investopedia.com/terms/o/operating-expense-ratio.asp

Kamal, K., \& Ab Wahab, L. (2014). Bangunan bersejarah: Kerosakan dan penyataan kaedah kerja pemuliharaan. Shah Alam: Penerbit UiTM.

Kamaruzzaman, S., \& Zulkifli, N. (2014). Measures for building lighting performance in Malaysian historical buildings: A systematic review. Journal of Surveying, Construction and Property (JSCP), 05(01), 1-15.

Keromo, P. (2000). Piawaian dan pelaksanaan konservasi monumen dan tapak tanah bersejarah. Bengkel Konservasi Monumen dan Tapak Tanah Bersejarah. Pulau Pinang.

Kim, S., Kevin, K., \& Cho, M. (2008). Assessing the economic value of a World Heritage site and willingness-to-pay determinants: A case of Changdeok Palace. Tourism Management, 28(01), 317-322.

Langston, C., Wong, F., Hui, E., \& Shen, L. (2008). Strategic assessment of building adaptive reuse opportunities in Hong Kong. Building and Environment, 43(10), 1709-1718.

Leaman, A., Stevenson, F., \& Bordass, B. (2010). Building evaluation: Practice and principles. Building Research and Information, 05, 564-577.

Mokhtar, M., \& Kasim, A. (2012). Motivations for visiting and not visiting museums among young adults: A case study on UUM students. Journal of Global Management, 03(01), 43-58.

National Centre of Sustainability. (2011). A short guide to monitoring \& evaluation. Retrieved from Evaluation Toolbox: http://www.evaluationtoolbox.net.au/index.php?option $=$ com_rubberdoc\&view $=\mathrm{d}$ oc\&id $=29 \&$ format $=$ raw

NIBS. (2009). Whole building design guide. Plan for fire protection. National Institute of Building Sciences.

Noor Fazamimah, M., Anuar, A., \& Yahaya, A. (2015). Role of cultural heritage in 
Muhammad Firzan Abdul Aziz

Post-Conservation Evaluation (PCE): Financial Performance of Adaptive Reuse Museums in George Town, Malaysia

sustainable historic urban development: Economic perceptions of stakeholders (perceived value). Jurnal Teknologi, 75(09), 51-55.

Rowley, J. (1999). Measuring total customer experience in museums. International Journal of Contemporary Hospitality Management, 11(06), 303-308.

Sapri, M., \& Pitt, M. (2005). Performance measurement in facilities management; State of knowledge. In F. Khosrowshahi (Ed.), 21st Annual ARCOM Conference, 7-9 September. 01, pp. 431-440. SOAS, University of London: Association of Researchers in Construction Management.

Taha, A. (2009). Museums in Malaysia: Challenges and development. In L. Noi, \& T. Eng (Ed.), ASEAN Museum Directors' Symposium, ASEAN Civilizations Museum. Singapore.

Received: January 2020. Accepted: $14^{\text {th }}$ May 2020 